\title{
POJETÍ UTRPENÍ A ZLA V EVOLUČNÍ TEORII TEILHARDA DE CHARDIN
}

\section{Františka Jirousová}

\section{Úvod}

Existence utrpení a zla ve vyvíjejícím se vesmíru je jedním z důležitých témat v díle prírodovědce, filosofa a theologa Pierra Teilharda de Chardin (1881-1955). Ve starších komentářích často vyjadřovaný názor, že Teilhard se zlu dostatečně nevěnoval, např́iklad proto, že mu jezuitská tradice „zřejmě byla na překážku v pochopení zla v dějinách a vnukla mu spíše úsměvný a laskavý postoj vưči dějinám a historii člověka" ${ }^{1}$ je po zpřístupnění celku jeho díla neobhajitelný.

Teilhardovy eseje a dopisy byly vydány ve 35 svazcích a vydávání není dosud ukončeno. Díky tomu také vyšlo najevo, že otázkou unde malum se tento jezuitský kněz začal zabývat už ve svých denících psaných na frontě první světové války, ${ }^{2}$ které se účastnil jako nosič raněných, a k tématu se poté vyjadřoval v mnoha dalších filosoficko-theologických esejích i v dopisech a denících, které psal až do své smrti. Textového materiálu je tedy velké množství.

Zároveň nelze popřít, že Teilhard používá pojmy poněkud nedbale a problém nikdy nevyložil systematicky, takže jeho řešení není úplně jasné. Jedním z hlavních důvodů by mohl být zákaz psaní filosofických a theologických esejů, který ho sužoval po celý život, publikovat směl pouze texty s prírodovědnými tématy. ${ }^{3} \mathrm{~V}$ tomto článku se pokusím nalézt společné jádro všech Teilhardových úvah o původu a smyslu utrpení a zla

1 P. Bendlová, Teilhard de Chardin, nová naděje katolicismu?, Svoboda 1967, str. 33 .

2 Viz P. Teilhard, Journal 26 août 1915 - 4 janvier 1919, Paris 1975; Genèse d'une pensée. Lettres 1914-1919, Paris 1961.

3 Hlavním podnětem k represím uvaleným na Teilharda církevními nadřízenými, včetně zákazu vyučování ve Francii a z toho plynoucího doživotního exilu, byla jeho snaha o evoluční reinterpretaci katolické nauky o dědičném hříchu (které se dotknu i v tomto textu). K těmto represím viz např. D. W. Viney, Teilhard: Le philosophe malgré l'église, in: K. Duffy (vyd.), Rediscovering Teilhard's Fire, Philadelphia 2010, str. 69-88. 
v evolučním vesmíru, vyjasnit použité termíny a podat vlastní návrh, jak zlo vymezit tak, aby zapadalo do pojmového rámce Teilhardovy teorie.

\section{Hlavní pojmy Teilhardovy evoluční teorie}

Prvním krokem na cestě $\mathrm{k}$ tomuto výkladu bude stručné představení hlavních tvrzení Teilhardovy evoluční teorie založené na křest'anské filosofii. Evoluce je v Teilhardově pojetí chápána jako postupné sjednocování mnohosti, od prvních atomů přes organismy až po lidskou společnost, konkrétně jako tápavý a tvořivý postup ke stále komplexnějším formám bytí. Pojem komplexita, ${ }^{4}$ na rozdíl od agregátu označujícího nejednotné nahloučení elementů, znamená „organizovanou, a tedy centrovanou různorodost" .5 Komplexní systém je celek složený z různých částí, které jsou navzájem provázané určitými vazbami, vztahy. Vztah je také základní kategorií Teilhardovy procesuální metafyziky, nazývané metafyzika unire - metafyzika sjednocování. ${ }^{6}$

Nárůst komplexity se děje výhradně pomocí sjednocování, které je vlastní činností každého komplexního systému. Jako nejčastější označení pro původce jednoty užívá Teilhard pojem „duch“ a definuje ho jako „svou podstatou schopnost syntézy a organizace“. ${ }^{7}$ Duch je tedy označení pro všechny typy vazeb či vztahů, konkrétně pro všechny formy komunikace, sdílení a interakcí mezi nejrůznějšími komplexními celky a uvnitř nich, díky kterým může být mnohost spojena do jednoho celku. Nejjednodušší formou „komunikace“ se rozumí vazby typu jaderných

4 Viz např. P. Teilhard, Misto člověka v přirodě, přel. J. Němec - J. Sokol, Praha 1993, str. 15, 23.

5 P. Teilhard, La Vision du Passé, str. 313: „... la complexité est une hétérogénéité organisée, - et par conséquent centrée." (Znění originálu je uvedeno, pokud se jedná o vlastní překlad.)

6 K Teilhardově metafyzice srv. studii C. J. Vale, Teilhard de Chardin: Ontogenesis vs. Ontology, in: Theological Studies, 53, 1996, str. 313-337; viz také Z. Plašienková - J. Kulisz, Na ceste s Teilhardom de Chardin, Trnava 2004, str. 66-75. Rozšířené přesvědčení, že Teilhard žádnou metafyziku neformuloval, pramení z toho, že dva jeho nejznámější texty (Vesmír a lidstvo a Misto člověka v prírodě) byly psány pro cenzory a prošly autorskými úpravami, když se Teilhard (marně) snažil deklarací „,vědeckého spisu“ obejít zákaz publikace theologických a filosofických textů. V českém překladu vyšel pouze jediný text, kde Teilhard metafyziku unire zmiňuje (Křest'anství a evoluce, in: P. Teilhard, Jak věřm, přel. V. Dvořáková J. Joneš, Praha 1997).

7 P. Teilhard, Vesmír a lidstvo, přel. J. Sokol, Praha 1990, str. 216. 
sil mezi subatomárními částicemi a vazby chemické (napřs. sdílení elektronu dvěma atomy). Mezi relace nejvyspělejší patří lidský jazyk, díky němuž je možné sdílet mýty a ideály udržující pohromadě všechna lidská společenství, a dále schopnost osobní lásky, jíž Teilhard věnoval mnoho svých filosofických úvah. Důležité pro Teilhardovo dílo je, že duchovní aktivita se objevuje od počátku vesmíru a to, co nazýváme hmotou, tedy určitý relativně stabilní tvar v časoprostoru, je podmíněno činností sjednocování, přesněji řečeno centrování.

Centrování spočívá v syntéze vztahů a aktivit všech částí kolem společného ohniska celku, které Teilhard nazývá vědomí. Podle Teilharda lze určitý typ vědomí připsat každému komplexnímu systému, přičemž jeho síla postupně narůstá až k vědomí lidskému, schopnému sebereflexe: „Vědomí se zvětšuje a prohlubuje proporcionálně k organizované komplexitě. "8 Aktivita všech typů vědomí má však společné jádro: Sjednocování mnohosti kolem společného středu a vytváření psychické neboli vnitřní stránky, od „psychik“ pro člověka nepostřehnutelných (např. u kamenů) až po hluboké nitro lidských bytostí obdařených sebevědomím.

V každém komplexním celku se tak ovlivňuje a vzájemně podmiňuje mnoho typů center. Jednou bytostí jsou do té míry, nakolik mají společné nitro, které se navenek vyjevuje jedním společným způsobem s určitými estetickými kvalitami (krystaly, symetrie rostlin, kresby na těle zvířat, všechny formy sebevyjádření u člověka). U člověka nese tento vnitřní obraz světa pečet' jedinečného, nenahraditelného úhlu pohledu na vesmír a tvoří podle Teilharda jádro nesmrtelné duše. Výrok „být více znamená více se spojit" ${ }^{\text {"9 }}$ deklaruje př́mou úměru mezi kvalitou vazebných sil, a tím i stupněm duchovní aktivity a komplexity. Komplexnější systém proto poznáme jak podle většího počtu různých typů vazeb, díky kterým může vytvářet obsáhlejší celky a působit závažnější typy změn, tak podle propracovanějších, různorodějších a mocnějších způsobů sebevyjádření.

Podmínkou vzniku a udržování jakýchkoli relací je energie. Energii vymezuje Teilhard jako „schopnost vazeb“, ${ }^{10}$ což znamená možnost být původcem pohybu, změny či přesněji řečeno šíření určitého vzruchu, který může vést k navázání spojení, udržování a obraně spojení starých,

8 P. Teilhard, L'Activation de l'Énergie (= L'Activation), Paris 1963, str. 107: „... la conscience grandit et s'approfondit proportionnellement à la complexité organisée de ces unités.“

9 P. Teilhard, Vesmír a lidstvo, str. 28.

10 Tamt., str. 37. 
ale také jejich rozbití za účelem vytvoření nových. Energie označuje v Teilhardově metafyzice vazbu v potenci. Disponuje jí každý celek, který může působit šíření různých typů vzruchů různými typy prostředí, opět podle stupně a typu své komplexity. Energie může být pojmenována různě podle prostředí, ve kterém se pohyb či vzruch šiří, jako např. elektrická nebo tepelná, energie myšlení či lásky, ale podstata zůstává tatáž: pohyb umožňující existenci vazeb.

Teilhard dělí energii na dva základní typy. ${ }^{11}$ Energie tangenciální pojmenovává vazby, díky nimž si dva nebo více systémů vyměňují různé zdroje: hmotu, energii samu nebo informace. Takovému sdílení ale musí předcházet aktivita energie radiální, která vytvárí podmínky pro existenci všech vazeb v komplexním celku. Toto vytváření podmínek interpretuji jako „sdělování formy“, tzn.: každý celek „sděluje“ určitým způsobem svým částem informace, které jsou nutné pro vznik a udržování různých typů spojení. Díky aktivitě radiální energie se tak po všech částech sjednocených $\mathrm{v}$ jednom celku šiŕí speciální typ „vzruchu“: zpráva o společné formě.

Formu v čistě abstraktním smyslu lze v návaznosti na Teilhardovy úvahy o organizaci, syntéze a zásadní důležitosti informace pro řízení sjednocované mnohosti vymezit jako soubor pravidel (bez nichž není organizace a syntéza možná), byt' v Teilhardově díle se konkrétní výklad o pravidlech nevyskytuje. Konkrétní realizací formy je pak určitý tvar, struktura v časoprostoru. Důležité je, že podstatou organizace a forem není v Teilhardově teorii primárně omezovat, ale umožnit vytváření různých tvarů a struktur za pomoci vztahů. Správné pravidlo omezuje jen proto, aby umožnilo činnost, která by bez něj nebyla realizovatelná. Nejjednodušším typem organizační síly (a tím i sdělování formy) je podle Teilharda gravitační síla, která „omezuje“ hmotu do jednoho prostoru, a tím umožňuje nesčetné typy aktivit, např. vznik života na planetách. Konkrétními strukturami vytvořenými podle této jednoduché formy (pravidla pro pohyb oběžnic kolem centra) jsou různé typy galaxií a slunečních soustav.

Teilhardova evoluční teorie je založena na tvrzení, že vývoj všech typů bytí probíhá samouspořádáním: „Podstata vesmíru je pro náš intelekt nejlépe definována jako proces samouspořádání."12 Samouspořádání v Teilhardově pojetí znamená podle mého názoru toto: V systému,

11 Autorka se otázkou podstaty radiální energie zabývá v připravované dizertační práci.

12 P. Teilhard, L'Activation, str. 241: ,... ce qui définirait le plus exactement pour notre intelligence la nature de l'Universe c'est ... le processus d',Autoarrangement "“ (anglicky selforganisation). 
jímž protéká energie, vzniká konkrétní provedení formy, tedy určitý tvar a struktura spontánně, zevnitř, bez determinujícího zásahu okolí, přičemž podle jedné abstraktní formy tak může vzniknout množina různých variant, které nelze předpovědět na základě znalosti této formy (pravidel systému).

Termín samouspořádání používá Teilhard jako synonymum pro svobodu nebo kreativitu. Přitom tvrdí, že určitý typ svobody se projevuje na každé evoluční rovině, ale proměňuje se podle stupně komplexity. ${ }^{13}$ Svobodu v tomto pojetí navrhuji chápat nejprve jako schopnost ř́dit se různým způsobem týmiž základními evolučními pravidly (formami), jak to vidíme např. $v$ geosfére na variantách krystalů utvořených podle několika neměnných geometrických soustav. Až na úrovni noosféry (sféra utvářená mezilidskými vztahy) je kreativita založena díky lidskému sebereflektujícímu vědomí na skutečné schopnosti záměrně vymýšlet také zcela nové formy uspořádání - vlastní psychiky, svého okolí, společnosti, uměleckého díla apod. U člověka dosahuje proto svoboda své plnosti a Teilhard ji nazývá také auto-evoluce.

Teilhard zároveň tvrdí, že evoluce je určitým způsobem řízena Bohem. Jestliže chce ale Bůh tvořit tak, aby umožnil samouspořádání, bude sám uspořádávat za „použití pokusných operací s velkými čísly“. ${ }^{14}$ Evoluci chápe Teilhard jako „stále účinnější řízení náhody“15 a jako proces postupující „,pokusným tápáním“. ${ }^{16}$ Tápání obecně znamená zkusmé hledání nových tvarů (např. náhodným pohybem nebo mutacemi), na úrovni noosféry pak záměrné testování různých typů uspořádání lidské společnosti. Tuto hlavní myšlenku Teilhardových spisů výstižně vyjádřil Edward Vacek: „Vưle Boží není předem daný plán, který má být objeven, ale spíše plán, který má být spoluvytvářen uplatněním našeho vlastního rozumu a srdce. “17 Bůh řídí evoluci především tak, že umožňuje tvořivost na všech evolučních rovinách. Jednak vytvárí obecná pravidla (evoluční zákony) pro vznik různých vazeb a tvarů, a jednak dává stvo-

13 Autorka se tématem podrobně zabývá v připravované dizertační práci.

14 P. Teilhard, Les directions de l'avenir (= Les directions), Paris 1973, str. 212: „... en utilisant le jeu tàtonnant des grands nombres“ (anglický překlad: „... using the tentative operation of enormous numbers").

15 P. Teilhard, L'Activation, str. 143: „[les centres organisés cosmiques] contrôlent de plus en plus efficacement le Hasard“".

16 P. Teilhard, L'Activation, str. 268: „Dans un pareil ,système tâtonnant““،.

17 E. Vacek, An Evolving Christian Morality: Eppur si muove, in: I. Delio (vyd.), From Teilhard to Omega, New York 2014, str. 159. 
ření materiál (energii), ze kterého je lze vytvářet; zajišt’uje tedy všechny podmínky, které jsou nezbytné pro rozvoj všech typů svobody. Jak s nimi následně bytosti naloží a jaké konkrétní tvary z nich vytvoří, záleží na stupni jejich komplexity.

Hlavním zákonem celé teorie ${ }^{18}$ je zákon diferencující jednoty: „Vesmír se prezentuje jako neustálý proces diferenciace (,personalizace'), diferenciace elementů je spojena s jejich postupným sjednocováním (,jednota diferencuje ‘)." ${ }^{19}$ Zákon vyjadřruje myšlenku, že vývoj bytí probíhá od nesjednocené mnohosti nesmírného počtu téměř totožných částic ke stále menšímu počtu propojených komplexních systémů, jejichž prvky se od sebe navzájem stále více odlišují a vykazují hlubší stupeň psychiky. Přitom nové vlastnosti, vazby a tvary - obecně nové kvality bytí - vznikají právě díky spojení mnohosti do jednoho systému pod společnou formou. Bez spojení by se elementy nikdy nezačaly vzájemně odlišovat a jejich psychika by se nemohla prohlubovat. Teilhardovy texty jsou známy hlavně kvůli úvahám o možnostech propojení zatím nerozvinutých lidských vědomí do jakéhosi vědomí kolektivního, v němž by se ovšem jednotlivá individuální vědomí nerozplynula, ale byla podílem na celku rozšířena a prohloubena.

Cílem evoluce je sjednocení celého stvoření s Bohem v plnosti bytí (pléróma), což konkrétně znamená nejvyšší stupeň jednoty v různosti, nebot' „nejvyšší diferenciace (individualizace) elementů se shoduje s jejich sjednocením v universálním Centru“ ${ }^{20}$ Toto centrum ztotožňuje Teilhard s Kristem, který je v jeho díle nazýván centrum světa nebo Forma mundi, ${ }^{21}$ Forma všech forem, ${ }^{22}$ nejčastěji však ,,bod Omega““ ${ }^{23}$

18 V Teilhardově díle lze nalézt několik odlišných návrhů na systematizaci hlavních evolučních zákonů jeho teorie, zde vycházím především z komentářů T. Kinga, např. Teilhard's Mysticism of Knowing, New York 1981, str. 31, a R. Faricyho, Teilhard de Chardin's Theology of the Christian in the World, London 1967, str. 59.

19 P. Teilhard, Lettres inédites. Lettres a L'Abbé Gaudefroy et a l'Abé Breuil, Monaco 1988, str. 112: „... l'Univers se présente comme un processus continuel de différenciation (,personnalisation'), - la différenciation des éléments étant liée à leur graduelle unification (,l'union différencie').“

20 P. Teilhard, Écrits du temps de la guerre (= Écrits), Paris 1965, str. 214: „... la différenciation (individuation) maximum des Éléments coïncide avec leur unification dans le Centre universel.“

21 Tamt., str. 392.

22 Tamt., str. 362. Shodně P. Teilhard, Journal, str. 385.

23 Výklad tvrzení v souvislosti s Pavlovými listy viz např. P. Teilhard, Science et Christ, Paris 1965, str. 82-84. 
Hlavním procesem, který ve vesmíru probíhá a jehož jsou všechny ostatní procesy určitými fázemi, je podle Teilharda vytváření těla Kristova úsilím všech entit a bytostí (jako bytost zde označuji každé centrum, komplexní celek v širokém slova smyslu: minerál, organismus i člověka): „Kristus má tělo rozprostírající se v celém vesmíru. “24 V závěrečné fázi evoluce, plérómatu, se působením Centra světa, Krista, do konečné harmonie shromáždí vše, co bylo samouspořádáním získáno z původní božské energie. Podle Teilharda božské evoluční zákony zaručí, že tohoto cíle bude jednou dosaženo, nicméně jaké konkrétní výdobytky ducha do konečné mozaiky plnosti bytí přinesou různé bytosti, ${ }^{25}$ včetně lidských, závisí na způsobu užití jejich svobody.

\section{Zákon transformace a chaos}

Otázkou je, z jakého důvodu dochází v samouspořádávajícím se vesmíru $\mathrm{k}$ nepořádkům, utrpení a projevům zla. Teilhardovy úvahy o zlu vycházely z přání reformulovat klasickou křest’anskou nauku o hřrišném pádu člověka a dědičném hříchu jako jeho následku. ${ }^{26}$

Racionální výklad biblického mýtu o Adamovi a Evě, ${ }^{27}$ který se v křest’anství prosadil, je dílem Augustinovým. Smrt a utrpení zasahující ty, kdo nejsou jeho původci, jsou zde chápány jako spravedlivý trest postihující celý lidský rod za překročení Božího zákona prvním lidským párem.

Nauka o hřŕšném pádu má svůj kořen v myšlence, která je zásadní nejen pro křest'anské pojetí člověka, ale také pro celou západní tradici. Člověk je bytostí, které lze přičítat odpovědnost za vinu, v křest'anské terminologii za hřích. Za zdroj zla je proto považována výhradně lidská svobodná vůle. Problémem je určit, odkud se vůbec bere sama náchylnost vůle ke zlu, když Bůh stvořil i lidskou vůli, a ta proto musí být, stejně jako

24 P. Teilhard, Écrits, str. 67: „Le Christ a un Corps mystique répandu dans l'Univers tout entier.“

25 Podle Teilharda má individuální nesmrtelnou duši rozhodně člověk. Jeho dílo lze dále interpretovat bud' tak, že díky tvůrčímu potenciálu lidské duše se do věčnosti přninášejí duchovní výsledky ostatních bytostí, nebo že každá z bytostí, která má nitro, má také nesmrtelnou složku, nikoli nutně individuální a osobní, ale např̀. druhovou. Podstatné pro jeho teorii je, že obsah duše se tvoří v průběhu života, takže to, co duše „odevzdá“, je jedinečný příspěvek závislý na každé sebemenší činnosti, kterou vykonala během života.

26 Tyto texty jsou shromážděny v desátém svazku Teilhardových sebraných spisů s názvem Comment je crois, Paris, 1969. 
lidská přirozenost, v základě dobrá. Tradiční odpovědí je, že náchylnost ke zlu je způsobena křehkostí stvoření, které pochází z ničeho (ex nihilo).

Cílem nauky o stvoření ex nihilo je obhájit Boha jako původce veškerého stvoření. Pokud by Bůh při tvoření jen opracovával předem danou matérii, kterou sám nestvořil, nelze ho chápat jako neomezeného vládce. Bůh je tvưrcem, ale také spasitelem, což pro člověka v důsledku znamená, že z každého zla existuje záchrana, v každé situaci existuje naděje, protože Bůh své stvoření neopouští. Pokud by existovala určitá látka, kterou Bůh nemá $\mathrm{v}$ moci, mohla by být chápána jako na něm nezávislý zdroj zla, jako je tomu také v některých naukách předpokládajících dualismus Boha a jemu rovnocenných mocností.

Základem Teilhardovy teorie o původu zla je evoluční adaptace myšlenky stvoření ex nihilo, která dovoluje chápat „nicotu“, či spíše křehkost bytí v procesuální podobě. Výchozím postulátem je následující tvrzení: Mnohost, „,(to jest ne-bytí v čirém stavu) [je] jediná racionální forma stvořitelné nicoty“. Tvưrčí akt si potom lze představit ,jako postupný proces pořádání a sjednocováni'“. ${ }^{28}$ Počáteční nesjednocená mnohost obdařená tvưrčí božskou energií (= výchozí stav stvoření) tedy není sama o sobě zlá, naopak je nezbytnou podmínkou vzniku jakýchkoli typů bytí. Lze ji ale nazývat nicotou, pokud v ní zatím není možné rozlišit žádné rozdíly, protože ty jsou podle zákona diferencující jednoty až důsledkem sjednocování na základě společné formy.

Vrozená křehkost bytí se u Teilharda mění ve vrozenou křehkost způsobenou neukončeností, nehotovostí stvoření, které bylo tvưrčím aktem Boha úmyslně vrženo do víru sebeuspořádání. Přitom v procesu vývoje existuje jedna fáze, v níž se křehkost bytí ukazuje nejvíce, a tou je fáze transformace, často spojená s chaosem. Chaos nastává tehdy, když stará struktura uspořádání zaniká, aby mohla být př́ípadně nahrazena novou, která bude moci sjednotit více různorodosti. Nutnost transformační fáze růstu komplexity je v Teilhardově teorii vyjádřena zákonem: „Přechod z jedné domény do druhé je ř́izen zákonem transpozice a transformace. “29 Tento přechod je nutný, protože ,žádná psychická entita nemůže ... růst donekonečna; vždy v určitý moment dosáhne ... kritického bodu, ve kterém mění stav“.30

28 P. Teilhard, Jak věrim, str. 110.

29 P. Teilhard, L'Activation, str. 323: „On a trouvé, pour passer d'un domaine à l'autre, la loi de transposition et de transformation."

30 P. Teilhard, L'Énergie humaine, Paris 1962, str. 76: „... aucune grandeur psychique, à notre connaissance, ne peut grandir indéfiniment: mais toujours, à un 
Proces změny stavu je vždy spojen s narušením stávajících vazeb systému, přičemž transformovaný celek může zachvátit velmi dynamický až bouřlivý pohyb - chaos, při kterém se z roztržených vazeb uvolňuje množství volné energie. Energie ve fázi chaosu není kvůli narušení formy celku usměrněná pevnými vazbami a může zasahovat i části systému, které by jinak zůstaly změny uchráněny. Stav chaosu může, ale nemusí vést k ustavení nových či pozměněných vazeb v celém systému nebo jeho části, a tím ke vzniku nového tvaru a nových možností vývoje. Teilhardovými slovy: „V procesu formování nemůže existovat žádný řád, aniž by v každé fázi implikoval nějaký chaos. “31

Jako př́klady transformace lze namátkou uvést některé stavové změny v různých typech komplexních systémů. Když voda začíná vřít, mění se i geometrické uspořádání (struktura) jejích molekul. Aby mohli někteří živočichové růst, musí proměnit svůj tvar (proměna kukly v motýla, svlékání hada z těsné kůže). Také všechny evoluční mutace DNA jsou prríkladem transformací, a to na úrovni druhů. Na rozdíl od biologických systémů je v moci člověka záměrně měnit také formy samé, abstraktní pravidla uspořádání. Když se napřr. reorganizuje velká instituce, je třeba změnit část pravidel, která umožňují vztahy jejích členů. Reorganizace může spočívat také v odstranění některé části celku, která růstu brání, nebo dokonce v rozebrání celé stávající struktury a jejím kompletním nahrazení jinou. Občasná nutnost přestavby se týká také „duchovních“ systémů. Př́ikladem z akademického prostředí je nutnost přepsat článek poslaný do recenzního řízení. Z vývoje osobnosti sem patří např. zkušenost psychoterapie provázená nutností změnit pohled na sebe sama, což je vlastně přímá transformace stávající struktury psychiky.

\section{Statistická nutnost nepořádku}

Teilhard tradičnímu pojetí dědičného hříchu vytýká určitý pesimistický antropocentrismus, který člověku přisuzuje tak velkou moc, že by jeho jediný čin proti Boží vůli dokázal poškodit celé stvoření a přivolat na lidstvo spravedlivý trest v podobě utrpení a smrti. ${ }^{32} \mathrm{~V}$ Teilhardově teorii jsou sklon k rozpadání, bolest a také smrt ve své podstatě přirozenou,

moment donné, elle rencontre quelqu'un de ces points critiques où elle change d'état.“

31 P. Teilhard, Les directions, str. 212: „Pas d'ordre en formation qui, à tous les degrés, n'implique du désordre."

32 K tomu více v P. Teilhard, Comment je crois, Paris 1969, str. 50, 51. 
dokonce nutnou součástí vývoje. Základem tohoto pojetí je tvrzení inspirované Ježíšovým výrokem necessarium est ut adveniat scandala (Mt 18,7), které přeloženo do Teilhardovy evoluční teorie znamená, že fáze transformace se s nutností občas nezdaří. Nikoli že se nezdaří vždy, ale že se nutně, tedy se stoprocentní jistotou tu a tam nezdaří. Protože postupné sjednocování mnohosti

„s sebou nese mnohá tápání a pokusy, nutně zato (od chvíle, kdy přestala být ,ničím") do sebe vstřebává bolesti a chyby. Vzato statisticky, je v př́padě rozsáhlého systému, který se pořádá, naprosto ,osudově dáno: 1) že se cestou objevují místní nepořádky ... a 2) že z těchto elementárních nepořádků od roviny k rovině (nebot' kosmická tkáň je organicky propojená) vznikají stavy nepořádku kolektivního, které se ve sféře života projevují jako bolest, počínaje člověkem jako hř́ch." 33

Následkem nezdařené fáze transformace je tedy určitý druh nepořádku, disharmonie. Teilhard vícekrát tvrdí, že různé druhy nepořádku včetně fyzické bolesti, a dokonce morálních prohřešků se objevují se statistickou nutností, už ale blíže nevysvětlil, co tím přesně myslí.

Statistika popisuje a předvídá chování a vlastnosti částic ve velkých souborech, jejichž složky se nechovají deterministicky, což jsou v podstatě všechny přirozené celky včetně lidských společenství. Vlastnosti těchto částic lze předpovídat pouze s určitou pravděpodobností. Vyplývá-li např. z obecného zákona, že v určitém souboru o počtu $n$ částic budou mít některé $\mathrm{z}$ nich určitou vlastnost, chybovost takové předpovědi je $\sqrt{ }$ n. To znamená, že ze 100 částic jich bude 10 , jejichž vlastnosti se budou lišit od vypočtené hodnoty. ${ }^{34} \mathrm{~V}$ př́padě souboru s počtem částic $10^{10}$ je chybovost předpovědi už jen $0,001 \%$. Při dostatečně velkém počtu částic lze nakonec ty, které se do předpovědi nevejdou, zanedbat jako nedůležité, což znamená nemající žádný vliv na vlastnosti systému, a systém lze v takovém př́padě považovat za determinovaný, tedy chovající se podle obecného zákona.

V Teilhardově evoluční teorii mají ale zásadní význam právě tyto odchylky, disharmonie. Kromě statistiky pracuje také s poznatky termodynamiky, využívá hlavně druhý zákon termodynamický, podle kterého

33 P. Teilhard, Jak věrim, str. 110.

34 Zpracováno podle G. M. Weinberg, An Introduction to General Systems Thinking, New York 2001, str. 13-19. 
při každé změně narůstá entropie, veličina vyjadřující míru rozptýlené energie nevyužité ke konání práce, tzn. v Teilhardově teorii množství energie, která nebyla využita pro vytvoření nějaké struktury. ${ }^{35}$ Druhý termodynamický zákon je podle mé interpretace přícinou toho, proč se části neřídí obecnou formou stále stejným způsobem: Stávající uspořádání jim neumožní využít všechnu energii k vytvoření harmonického tvaru. Jevy či struktury vytvářené částmi, které se „nevejdou“ do obecné formy celku při procesu transformace, lze nazvat disharmonie. Některé z nich mohou vést $\mathrm{k}$ nalezení nové varianty tvaru, nové interpretace obecné formy, z některých z nich může za určitých podmínek vzniknout to, co nazýváme utrpením nebo zlem, k čemuž se vrátím za chvíli.

V základě jsou ale disharmonie především nutnou podmínkou postupu k vyššímu typu komplexity a vzniku nových typů bytí, tzn. evoluce samé. Pokud by se totiž všechny části zapojené do transformace řídily přesně obecnou formou, nemohlo by se nikdy stát, že dojde k disharmonii, a vznikající tvary by se opakovaly jako výrobky na běžícím pásu. Situace chaosu je vždy spojena s nedostatkem zdrojů a ztrátou některých možností spojení, důsledkem čehož se nepodaří navázat vazby podle obvyklého způsobu interpretace pravidel. Č́sti, které se ocitly v této disharmonii, jež se na komplexnějších rovinách projevuje jako nedostatek nebo strádání, jsou bud' doslova nuceny hledat nové typy spojení, nebo díky náhodě navážou spojení, které by jinak nevzniklo. Je možné, že všechny nové typy relací, které vedou evoluci dál, vznikly tímto způsobem.

Evoluční pokrok označuje v Teilhardově teorii objevení se nové možnosti sebeuspořádání (sebeurčení) každého prvku systému, což konkrétně znamená, že se objeví nová účinnější relace, v noosfére typicky nová možnost komunikace - spojení (písmo, železnice, telegraf, bezdrátový přenos) nebo transformace jedné energie na druhou (parní stroj, elektrická energie), a tím i možnost vytvoření nového typu struktury. Jejich využití pro růst či umenšení komplexity je otevřená věc, pokrok pojmenovává pouze možnost správného využití nové vazby.

Evoluce v Teilhardově pojetí postupuje právě díky kombinaci nedostatečných zdrojů a touhy po vyšším stupni bytí, vposled po dosažení jeho plnosti, která je imanentní každému evolučnímu prvku a žádá si „více moci ... více jednat a více být ${ }^{\text {“ }}{ }^{36}$ Tato vrozená tendence má

35 K výkladu Teilhardova díla za využití poznatků nerovnovážné termodynamiky viz J. Salmon, Teilhard and Prigogine, in: Teilhard Studies, 16, 1986; J. Salmon - N. Schmitz-Moormann, Evolution as a Revelation of a Triune God, in: Teilhard Studies, 46, 2003.

36 P. Teilhard, Vesmir a lidstvo, str. 208. 
u všech bytostí společný základ, nebot’ „vesmírná hmota je oživována absolutním prvenstvím bytí před nicotou“, ${ }^{37}$ podle stupně komplexity systému se ale její působení proměňuje, $v$ biosféře se projevuje jako instinkt zachování druhu a na rovině noosféry ji Teilhard nazývá nejčastěji „chut' žít“. Vyjadřuje imanentní „tušení“ každého evolučního prvku, že množství využitelné energie je mnohem vyšší, než je díky jeho stávající struktuře dostupné.

\section{Disharmonie a utrpení v geosféře a biosféře}

Důležitost fáze transformace pro evoluci zdůraznil jeden z nejlepších Teilhardových komentátorů Thomas M. King, podle něhož „mluvit o chaosu, náhodě, nebezpečí nebo nestabilitě není ještě to samé jako mluvit o zlu, protože toto všechno může přinést jak pozitivní, tak negativní výsledky“. ${ }^{38}$ Nicméně „,ve chvíli, kdy je možný tvořivý postup, může dojít také k těžkému nezdaru“. ${ }^{39}$ Je to právě tato fáze vývoje, ve které může do procesu uspořádání nejsnáze vstoupit utrpení nebo zlo. Podobně jako u většiny Teilhardových pojmů lze i v př́padě disharmonie rozlišit její tři formy podle evoluční roviny a stupně komplexity:

„Fyzické disharmonie nebo rozklad v oblasti předživého; utrpení v oblasti živého; hřích v doméně svobody. “40

Ne každá disharmonie, nejednota či ne-pořádek jsou tedy utrpením nebo zlem. Utrpení a zlo (hřích) jsou až zvláštním případem obecnějšího pojmu disharmonie.

Na rovině geosféry, jejíž elementy nemají nervovou soustavu, není ještě možné mluvit o bolesti nebo utrpení. Geosféra netrpí, pouze se zde vyskytují různé typy nesouladu, např́klad v podobě různých vad krystalových mřížek. Fyzik by snad byl schopen uvést, jaký význam mají tyto nepravidelnosti v realizaci formy pro nové možnosti spojení. Evidentní evoluční význam má např. transformace při výbuchu sopky

37 P. Teilhard, L'Activation, str. 243: „,... que de se représenter la masse cosmique comme animée ... d'une primauté absolument accordée à l’Être sur le Néant.“

38 T. M. King, Teilhard, Evil and Providence, in: Teilhard Studies, 21, 1989, str. 8.

39 Tamt.

40 P. Teilhard, Les directions, str. 212: „Dysharmonies ou décompositions physiques dans le Pré-vivant, souffrance chez le Vivant, péché dans le domaine de la Liberté.“ 
nebo posunech zemského povrchu, kdy vznikají nové minerály, horniny a celé zemské útvary.

Od úrovně biosféry sestávající z organismů s nervovou soustavou je ale každá radikálnější změna struktury doprovázena bolestí, případně strachem a dalšími emocemi, které mají evoluční význam. Jednou ze zásadních funkcí bolesti je varování komplexního systému před poškozením jak zvenčí, tak zevnitř, je tedy nezbytná pro zachování stupně dosažené komplexity a jako funkce celku je automaticky navázána na porušení jeho jednoty. Signály varující před ohrožením dosaženého stupně komplexity nabírají na síle zároveň s tímto stupněm. Bez této funkce nervového systému by jakýkoli organismus velmi brzo zahynul.

Bolest přirozeně provází také růst komplexity a tvorbu nového, nebot' „kategorií tvorby je námaha“. ${ }^{41} \mathrm{Ne}$ každý růst musí být nutně spojen s bolestí, ale stav, při kterém se nové rodí př̀etvořením starého, je s ní spojen vždy. Určitá míra bolesti je ukazatelem hranic zdravého růstu, jako např. při cvičení: Pokud nebolí nic, sval se nerozvíjí, pokud je ale bolest př́liš veliká, sval se poškozuje. Bolest růstu bývá zároveň provázena slastí, protože je spojena s navýšením intenzity energie v organismu. Podobně činy, kterými organismus prokazuje svou sílu, jako např. boj o život, mohou být provázeny slastí (jak je známo také z lidské zkušenosti). Dalším prŕíkladem spojení slasti a bolesti jsou bolesti porodní, kterými matčino tělo vyjadřuje nejen velké úsilí, ale také ztrátu jednoty s dítětem, tedy ztrátu vysokého stupně komplexity. Zároveň může být př́ítomna hluboká radost, provázející každý tvưrčí čin vedoucí k větší plnosti bytí, protože umožnit samostatný život nové bytosti je ještě vyšší stupeň komplexity než s ní být sjednocen jako s bezmocným tvorem.

Bolest spojená s umenšením komplexity vzniká při neúspěšné transformaci nebo jako následek kompetice mezi organismy nebo orgány $\mathrm{v}$ těle $\mathrm{v}$ prostředí s nedostatečnými zdroji. V biosféře se obecně projevuje jako umenšení životního prostoru: následky soubojů, různé nemoci či vrozené slabosti. Pokud tyto ztráty neumožňují další růst u jedince, kterého postihly, můžeme je nazvat utrpením. $Z$ hlediska biosféry jako harmonického, dokonalého celku jsou ale tyto ztráty komplexity vždy kompenzovány růstem na jiném místě, mají tedy evoluční význam. Ukazuje se totiž, že např. existence predátorů jako součásti potravních řetězců je nezbytným prredpokladem nesmírné různorodosti biosféry. Organismus také není schopen zabíjet či bojovat jen kvůli tomu, aby umenšil kom-

41 P. Teilhard, Jak věřim, str. 50. 
plexitu organismu jiného. Zvíře je nevinné, nepáchá zlo, protože i když působí utrpení, cokoli dělá, dělá instinktivně podle zákona diferencující jednoty: Jeho prŕpadná agrese (typ spojení) nebo slabost umožní růst komplexity celku, tedy zvýšení spojené různorodosti.

Také smrt je přirozenou součástí vývoje. Z hlediska evolučního pojetí universa je představa nesmrtelného člověka situovaného do ráje, tedy dokonalého a plně dokončeného stvoření rozvinutého v celé své intenzitě a harmonické různorodosti, absurdní. Právě smrt byla v tradiční křest’anské nauce chápána jako trest za hř́ch. To Teilhard jednoznačně popírá, protože smrt je $\mathrm{v}$ jeho teorii také jedním $\mathrm{z}$ druhů transformace: „V jaké formě se smrt představuje v osobním vesmíru? - Jako přeměna." 42 Rozklad komplexních systémů byl ve vesmíru přítomen od samých počátků, tedy dávno předtím, než se objevil člověk. Smrt je „vepsána př́mo do fyziochemie hmoty, vyjadřuje svým způsobem atomickou povahu struktury vesmíru“ ${ }^{43}$ protože je výrazem nutnosti transformace každého uspořádání mnohosti na cestě $\mathrm{k}$ vyšší jednotě. Kdyby existovaly pouze vazby bez možnosti rozpojení, nemohlo by nikdy vzniknout nic nového a vývoj vesmíru by ustal ihned po vytvoření prvních částic, nebo by „vývoj“ spočíval pouze v kvantitativním růstu, přidávání téhož. To platí také ve vztahu k noosféře: „Bez pokusných tápání a bez selhání, bez smrti a bez planetárního sevření, by člověk, jako lidský druh, zůstal nehybný." "44 Pro lidskou duši je smrt jediný způsob, jak završit svůj individuální vývoj. Problém člověka není ve smrti samé, ale v tom, že se smrti bojí.

\section{Disharmonie a zlo v noosféře}

Morální zlo, v křest’anské terminologii hřích, se vyskytuje pouze v noosféře, jak Teilhard uvádí např́iklad v následujícím rozlišení disharmonií ve třech sférách evoluce: ,zóna čistě materiální dezintegrace - zóna utrpení - zóna provinění“ “. ${ }^{45}$ Obecně označuje Teilhard zlo jako porušení

42 P. Teilhard, L'Énergie humaine, str. 108: „Comment se présente la Mort dans l'Univers Personnel? ... Comme une métamorphose.“

43 P. Teilhard, Jak věrim, str. 105.

44 P. Teilhard, L'Activation, str. 319: „Sans tâtonnements et sans ratés, sans mort et sans serrage planétaire, l'Homme demeurerait humainement immobile.“

45 P. Teilhard, L'Activation, str. 215: „... zone de la Désagrégation purement matérielle, - zone de la Souffrance, - zone de la Faute.“ 
jednoty: „Existuje pouze jedno Zlo = nejednota.“46 Z předchozího výkladu je ovšem zřejmé, že nejednotou, tedy narušením stávajících vazeb, se vyznačuje také stav chaosu při transformaci, který je sám o sobě hodnotově neutrální, záleží až na jeho výsledku. Jaký speciální typ nejednoty tedy označují pojmy provinění či zlo? Pro bližší vysvětlení zkusím nejdřive upřesnit, co to znamená „správná jednota“, komplexita neboli „sdílené bytí“.

Teilhardova teorie je založena na představě vztahové „sítě“ rozprostřené jak horizontálně, tak vertikálně, a to v prostoru i v čase. Časová sít' je výsledkem faktu, že podoba komplexnějších celků je závislá na tom, co se podařilo vytvořit v předchozích sférách vývoje. Dvě z nich, geosféra a biosféra, již svoji evoluci dokončily a nyní podporují rozvoj dosud nedokončené noosféry, jejíž typické vazby by nemohly fungovat bez využití zdrojů anorganických a organických celků. $Z$ hlediska horizontálního vytvárí kolem sebe každá bytost sít' vztahů, skrze niž přicházejí zdroje, které užívá, a odcházejí ty, které po transformaci zase posílá do sítě $\mathrm{k}$ užívání dalším bytostem nebo jako odpad.

Z hlediska vertikálního, tedy hierarchického, se na každém uzlu sítě nachází jiná bytost, která může řídit množství dalších méně komplexních bytostí - zajišstovat zdroje $\mathrm{k}$ jejich činnosti a ovlivňovat je svou vlastní formou. Přitom každé z těchto podřazených komplexních center má zase svoji vztahovou „pavučinu“, svá pravidla fungování (formu) a své typické transformace, jako je tomu např. u buněk v lidském těle. Také v lidském společenství je každý jedinec součástí vyššího celku, který má své centrum $\mathrm{v}$ podobě společně sdíleného ideálu, a je tedy pod vlivem nadřazených pravidel.

V komplexním systému, na rozdíl od agregátu, musí fungovat určité „sdílení bytí“, což je další termín, který Teilhard přesně nevyložil. Podle mého názoru se harmonické systémy vyznačují především tím, že v nich zdroje při transformacích cyklicky obíhají, a tím umožňují koexistenci různých typů bytostí. ${ }^{47} \mathrm{~V}$ geosférée jsou to např. různé koloběhy látek, v biosféře např. vegetační a metabolické cykly, ale i potravinové řetězce, ve kterých jsou zapojeni predátoři. Zákon diferencující jednoty by pak bylo možné chápat také tak, že pokud se podaří dosáhnout cyklického oběhu zdrojů, tzn. správného sdílení, diverzita vzniká automaticky.

46 P. Teilhard, Science et Christ, str. 109: „Il n'y a qu'un seul Mal= la désunion.“

47 Hlavní inspirací pro tento výklad mi byla teorie systémů K. Berriena, viz General and Social Systems, New Brunswick 1968, a vynikající kniha o sebeorganizaci organismů M.-W. Ho, The Rainbow and the Worm: The Physics of Organisms, New Jersey - London - Singapore 2008. 
Kritériem stupně komplexity je ,šíře vědomí“. Teilhard tvrdí, že tato šíře může u lidské psychiky (či duše) růst neustále, za předpokladu, že to umožní formy, se kterými vědomí pracuje. Na rovině noosféry jsou projevem touhy „být více“ všechny typy lidské expanze: Touha po moci, bohatství, plození, vědomostech a výzkumu (Teilhardovo hlavní téma), uznání, lásce, vztahu s mocnější silou, tedy touha náboženská, obecně všechny způsoby, kterými může člověk rozšířit svoji komplexitu. Teilhard žádný z těchto způsobů nekritizuje ani nepovažuje za zcela špatný ani př́liš nezdůrazňuje jeden na úkor druhého, naopak ukazuje, že všechny typy lidských tužeb se vzájemně doplňují a mohou mít konstruktivní i destruktivní stránku podle toho, zda komplexitu opravdu rozšiřují nebo umenšují.

K rozšíření vědomí by měly sloužit nejsilnější vazby noosféry: myšlení, láska a víra (spojená se starostí o ideály). „Správná jednota“ rozšiřující vědomí znamená nalezení způsobu, jakým mohu sdílet něco z jedinečného, nezastupitelného obrazu světa, který v sobě nese podle Teilharda každá lidská bytost, ${ }^{48}$ a vysílat to jako určitý zdroj do vztahové sítě, jíž se účastním, tak aby to přispívalo také k sebevyjádření ostatních. Ve svých etických spisech ${ }^{49}$ Teilhard zdůrazňuje, že to mohou být činnosti zdánlivě nepatrné, jen když jsou vykonávány s láskou a s úctou $\mathrm{k}$ jedinečnosti bytostí zahrnutých ve vztahové síti konkrétního jedince. Obdoba takového sdílení „obrazů světa“ probíhá ve všech evolučních sférách, čehož výrazem jsou např. ornamenty na tělech rostlin a zvířat - vnější výrazy jejich psychiky -, a ostatně všechny formy komunikace. Šíře vědomí se dá „měřit“ právě rozsáhlostí a různorodostí vztahové sítě, v jejímž rámci uvažuji o svých činech a na jejíchž cyklech zdrojů se vědomě podílím: Mé vlastní potřeby, rodina, vesnice, stát, Evropa, Země, galaxie a nakonec Bůh a jeho vyvíjející se vesmír.

Vztahové sítě noosféry jsou nedokončené, protože zde dosud nejsou sladěny cykly sdílení, což je vidět už jen na množství nevyužitého odpadu, který vzniká z lidské činnosti. V ostatních sférách slouží „odpad“ jako zdroj energie pro jiné systémy. Nicméně nedokonalost forem noosféry není výrazem zla, ale lidské auto-evoluce. Kompetice se na úrovni noosféry týká právě pravidel uspořádání, tzn. různých ideálů, náboženských i politických, jejichž pokusné aplikace na společnost tvoří lidské

48 Viz např. P. Teilhard, Vesmír a lidstvo, str. 217.

49 Viz např. P. Teilhard, Božské prostředi, in: Chut'žit, přel. V. Frei - J. Sokol, Praha 1970, str. 7-118. 
dějiny a představují vlastní úkol člověka jako bytosti svobodné v nejvyšší míře, tzn. schopné se záměrně podílet na díle stvoření.

Pravidlo, které platí v předchozích sférách, že chaos transformace je podmínkou vzniku nových typů bytí, platí o to více zde. Chaosem, krizí a nejednotou je sám stav lidských forem a pravidel. Noosféra je od svého počátku ve stavu transformace a její zdánlivě trvalé společenské útvary budou vždy znovu podrobeny změně. Nelze proto zlo definovat pouze jako „nejednotu“, protože ta je zde něčím přirozeným. Bude proto třeba najít ještě další znak, který k ní přistupuje. Ani Teilhard, ani T. King ale zcela nevyjasnili, jak zlo ve fázi transformace vzniká; v následující části textu zkusím proto podat vlastní návrh.

Jednou ze zvláštností člověka je podle Teilharda to, že „rozeznává dva železné zákony, před kterými se zvíře sklání bez porozumění (a proto bez utrpení), nutnost zapřít sám sebe kvůli růstu a nutnost zemřít, a cítí (čím hlouběji a pravdivěji je člověkem) jejich tíži a hrůzu“. ${ }^{50}$ Toto poznání vede ke specificky lidskému strachu z umenšení komplexity. Každá bytost má nejen přirozenou tendenci k růstu, ale hlavně úpornou snahu o zachování stupně komplexity, kterou na evoluci vydobyla. Organismy se mění ne díky tomu, že chtějí, ale díky náhodným mutacím (chaosu) při manipulaci s DNA, jsou tedy ke změnám nuceny kombinací evolučních zákonů - tzn. spojení je nutnou podmínkou vzniku nového a tvưrčí rolí náhody a entropie.

Také člověk je ke změnám většinou nucen silami, které nemá v moci, a díky své jedinečné schopnosti představovat si to, co není, a porozumět povaze pravidel, má z každé větší změny strach. Protože není nikdy zaručeno, že se změna podaří, a často je při ní třeba něčeho se vzdát (,,zapřít sám sebe“), aby byl jinde umožněn růst, a protože je mnoho změn spojeno s bolestí a utrpením, člověk často transformaci odmítne a snaží se setrvat na určitém stupni komplexity, uzavře se ve svém relativně klidném světě, aby si zajistil aspoň tento stupeň bytí.

Touha duše po růstu brzděná strachem se může přelévat do čistě kvantitativního uspokojení, při kterém zdánlivě nehrozí transformace s nebezpečím ztráty (např. hromadění peněz, ,zábavných zážitkư“ nebo informací). Patří sem např. také intelektuální obrana proti změně, jak se ukazuje ve fundamentalismech všeho typu, hledajících věčný, neměnný řád uspořádání lidstva. To všechno přímo i nepřímo přispívá ke vzniku

50 P. Teilhard, La Vision du Passé, str. 106: „Les deux lois de fer auxquelles se pliaient sans comprendre (et donc sans souffrir) les animaux, la nécessité de se renoncer pour croître et la nécessité de mourir, il les dégage et il en éprouve (d'autant plus qu'il est plus homme) la pesanteur et l'odieux.“ 
vztahů, které neumožňují cyklování zdrojů (materiálních, emocionálních či intelektuálních) a vytváření funkčních vztahových sítí. Důsledkem je např. rozevírání rozdílů mezi bohatými a chudými, zestejňování namísto rozrůzñování, poškozování životního prostředí, násilí jako reakce na ztrátu důstojnosti apod.

Otázkou je, kdy se strach mění ve zlo. Na tuto otázku už Teilhard nedává výslovnou odpověd'. Při návrhu upřesnění jeho pojetí zla rozliším nejprve tři fenomény: Cíl, motiv a vztah, přičemž vztahem míním určité jednání realizované na základě obou prve uvedených složek.

Ohledně motivu zlého jednání vycházím z Teilhardových úvah o tom, jak se strach může změnit $\mathrm{v}$ odpor $\mathrm{k}$ bytí. Ztížené možnosti nalezení osobitého př́spěvku celku v nedokonalých a chaosu vystavených vztahových sítích mohou na člověka dolehnout tak těžce, že propadne odporu k životu samému, úsilí evoluce mu přestane dávat smysl a ovládne ho pocit umenšení. Teilhard na jednom místě označuje termínem ,zlé“ samo vědomí umenšení komplexity: „To zlé ve Zlu spočívá nikoli v bolesti, ale v pocitu umenšení skrze bolest. “51 Přikláním se spíše k názoru, že pocit umenšení, tzn. ponížení vlastní osoby nebo nějaké ztráty předchozích možností, vede ke specifické náladě duše, která sama o sobě ještě není zlá, ale může být zdrojem zlého jednání. Duše může reagovat tímto naladěním také na utrpení způsobené vlivy z geosféry (přírodní katastrofy) nebo biosféry (nemoci).

Jako základ či pramen zlého jednání budu tedy chápat pocit umenšení a ponížení. Ten může snadno vést $\mathrm{k}$ něčemu, co lze nazvat „zlé naladění. Takovéto rozpoložení je podle mé interpretace obráceno proti druhým bytostem, které jsou vnímány jako ve své podstatě špatné. Označení nějaké bytosti jako špatné však znamená zneužití schopnosti soudit, hodnotit. Člověk, na rozdíl od zvířete, umí rozlišovat na abstraktní škále hodnot, s principiální možností dojít až do extrémů, tedy vytvořit ideál nebo označit něco za absolutně zlé. Správné užití schopnosti hodnotit se týká abstraktních pravidel a forem a především vztahů na nich založených, protože podmínkou tvoření správných forem je právě možnost označit je samé nebo vztahy podle nich realizované za horší nebo lepší, případně za zcela zavrženíhodné. Domnívám se však, že označit takto i nějakou bytost samu znamená zneužití této schopnosti. Takovéto označení jiné bytosti leží v základě zlého jednání a je živeno strachem.

51 P. Teilhard, L'Énergie humaine, str. 109: „Ce qui fait le mal du Mal, ce n'est point la douleur, mais le sentiment de diminuer par la douleur.“ 
Tím se vlastní umenšení přenáší na druhého člověka: Ponížený ponižuje a umenšuje druhého, a tím dává př́ležitost ke vzniku zla.

Jako zlou v pravém slova smyslu je třeba označit až realizaci určitého vztahu, tzn. záměrné jednání motivované zlým naladěním a vedené nějakým cílem. V křest’anské tradici musí být totiž zlý čin záměrný, tedy obsahovat volní prvek, aby za něj bylo možné člověka činit zodpovědným. Jelikož zvíře zlo nepáchá, bude zlé jednání spojeno patrně se specificky lidskou schopností sledovat dlouhodobě nějaký cíl (ideál), která je podmínkou lidské výsady aktivně vytvářet a měnit pravidla uspořádání.

Cíl je třeba odlišit od motivu: Strach, pocit ponížení, hořkost nebo nenávist jsou motivy a nebývají ovlivnitelné vůlí, nejsou tedy zlem a je spíše zdravé si je přiznat, aby bylo možné je změnit. Ovšem cíle stanovené a vyživované těmito motivy, které jsou bezpochyby v moci lidské vůle, navrhuji považovat za původ zlého jednání, hříchu, pokud jsou aktivně naplňovány pomocí uskutečnění nějakého vztahu. Realizace cílů stanovených na základě „zlého naladění“ (nejčastěji mají podobu záměru někomu ubližit, pomstít se, pomluvit, a to i ve vztahu k sobě samému) vede ke vzniku specifické „,nejednoty“, tedy narušení vztahových sítí, a tím k dalšímu umenšení komplexity zasažených bytostí (včetně vlastní duše) nebo zabraňování v jejich růstu, čímž se roztáčí další kolo chaosu a „zlých naladění“ bytostí závislých na takto narušené vztahové síti.

Teilhard používá pro narušené vztahy termín „vnější temnoty“ („Les ténèbres extérieures = l'ISOLEMENT"). ${ }^{52}$ Ty se snadno mohou stát temnotami vnitřními, pokud vedou k utrpení, zoufalství, duševní nemoci apod. Mohou mít různé podoby, z nichž i ty zdánlivě „lehké“, jako šiřrení pomluv, mohou vést $\mathrm{k}$ naprosté izolaci člověka, a jsou proto skutečným zlem. Také nekonání ve smyslu lhostejnosti k tomu, co se děje v okolí, bývá založeno na velmi konkrétních cílech („,mít svůj svatý klid“, užívat si bez vynaložení úsilí, apod.). Lhostejnost a nekonání jsou také vztahem, protože mohou neprímo působit změny, které by v případě aktivity nenastaly, a podporovat tak přímo či nepř́mo různé typy zla.

Nejvýraznějším příkladem narušených patologických forem vztahů jsou totalitní systémy, jejichž existence je umožněna právě lhostejností nebo strachem. Podle Teilharda spočívá jejich evoluční nefunkčnost především v potlačování různosti. Lze také říci, že pokud jsou jejich pravidla organizace založená na vyloučení nějaké skupiny a jejich aplikace nutně provázena nenávistí a pohrdáním, lze je nazvat zlými už

52 P. Teilhard, Notes de retraites 1919-1954, Paris 2003, str. 220. 
z podstaty. ${ }^{53}$ Teilhard se těmito tématy zabývá ve svých textech o formách politického uspořádání, ${ }^{54}$ což by bylo téma na samostatný článek nebo monografii. 55

Z Teilhardovy teorie plyne, že vše může být uspořádáno tak, aby každá z bytostí našla své jedinečné místo v celku, protože vesmír je $\mathrm{v}$ možnosti proměnitelný $\mathrm{v}$ dokonalé tělo Kristovo. Dokonalý celek si lze představit jako nesmírnou pyramidu sítí v čele s Kristem - formou všech forem a centrem energie, kde každý bod tvořený lidskou duší je jedinečný právě díky svému umístění, tj. poskytuje jedinečný úhel pohledu na vesmír, a proto může dodávat do celku i jedinečný zdroj pro rozvoj vědomí ostatních. To, že se zatím nepodařilo takovou sít' vytvořit, neznamená, že má člověk právo označit nějakého jiného člověka, nebo dokonce celou skupinu lidí za tak špatné, že je nutné je z této sítě vyloučit. Naopak kritizovat špatná pravidla a vztahy vedoucí k vylučování z této „sítě“ a starat se o vytváření lepších je nejdůležitější lidskou povinností.

\section{Kř́iž jako symbol evoluce}

Výsadou člověka je, že má pravidla uspořádání tvořit a ta špatná a jejich důsledky také sám napravovat. Problém spočívá v tom, že v mnoha situacích není náprava $v$ silách jedince ani skupiny. Odpor k životu, taedium vitae, který vzniká jako reakce na nemožnost jednat, je podle Teilharda „hlavní překážka formování noosféry“. ${ }^{56}$ Aby byl člověk ochoten pokračovat v evoluci - duševním růstu -, musí mít nějakou záruku účinné pomoci z této lidské situace, křest’anským termínem „vykoupení“. Vykoupení v evolučním vesmíru znamená také „kompenzaci za statistické nepořádky“ ${ }^{57}$ tedy nějakou formu náhrady za vznikající př́ležitosti ke

53 Pravidlo zlé ,z podstaty“ by bylo takové, jehož vlastním cílem je např. umožnit vraždu nebo umenšit životní prostor; na rozdíl např. od pravidel sebeobrany, jejichž cílem je ochrana zdraví, života a majetku.

54 Srv. např. P. Teilhard, L'Essence de l'Idée de Démocratie, in: L'Avenir de l'Homme, Paris 1959; Sauvons l'Humanité, in: Science et Christ; L'Heure de choisir, in: L'Activation de l'Énergie; Víra v mír, in: Misto člověka v prírodě.

55 Viz např. stále aktuální komentář ke všem Teilhardovým politickým tématům: P.-M. Mathieu, La pensée politique et économique de Teilhard de Chardin, Paris 1969.

56 P. Teilhard, L'Avenir de l'Homme, str. 261: „,... un empêchement radical à la formation d'une Noosphère“.

57 P. Teilhard, Les directions, str. 213: „,.. la compensation pour les désordres statistiques". 
zlu v podobě aktivní pomoci na cestě $\mathrm{k}$ vyšší jednotě. Biosféra nepotřebuje vykoupení, protože rostliny ani zvířata neodmítly kvůli utrpení ve vývoji pokračovat.

Co to ale konkrétně znamená ve vztahu k lidskému utrpení? Pocity umenšení a ponížení v reakci na bolest a strach mohou být prŕčinami zla, ale „Boží prozřetelností se z nich mohou stát velkolepé nástroje duchovního růstu““. ${ }^{58}$ Klade se proto nejprve otázka, v jaké fázi procesu transformace máme právo se vzdát vlastní aktivity a spoléhat už jen výlučně na Boží pomoc. To znamená: Jak rozpoznat, kdy ještě bolest plní ochrannou nebo stimulující funkci a kdy je už jen zbytečnou trýzní?

V evoluci, která znamená podíl na božském tvoření, je po všech bytostech požadována především aktivita, sjednocování, která je také přirozenou spoluprací se stvořitelem. „Když se umenšování poprvé přiblíží, nemůžeme najít Boha jinak, než že se postavíme na odpor tomu, co přichází, a že uděláme vše, co je v našich silách, abychom se tomu vyhnuli." "59 To znamená snažit se s vynaložením úsilí proměnit bolest v tvůrčí energii pro nalezení nové jednoty duše, nepropadnout tedy ,zlému naladění“. To občas předpokládá zapojení agresivity či nekompromisní tvrdosti vůči sobě samému, aby byl překonán pocit ublíženosti a záštiplné bezmoci. Že je umenšení komplexity Boží vůlí, mohu říci „tam, kde veškerá má činnost směřující k lepšímu bytí ... je stále pohlcována silami, jež mě chtějí zastavit nebo obrátit zpět", 60 tedy v okamžiku, kdy z lidského hlediska nezbývá žádná naděje.

Teilhard chtěl ukázat kř́ž jako symbol podílu božské tvưrčí síly na dramatickém evolučním procesu. To lze chápat podle mého názoru takto: Všechny transformace se ve skutečnosti dějí uvnitř Kristova těla a každé utrpení jakékoli bytosti je také jeho utrpením. Kristovo lidské vtělení a jeho smrt byly nutnou podmínkou, aby se mezi Kristovou duší a všemi dalšími dušemi ustavilo nezrušitelné spojení, vazba nezrušitelná žádným chaosem. Tento výklad by mohl ilustrovat např. následující text:

„Máme jen velmi malou evidenci o způsobu, jímž náš Pán zakouší své mystické tělo, aby se z něj těšil, ale můžeme si učinit určitou predstavu, jak může zacházet s jeho utrpením. Jediný způsob, jakým si můžeme uvědomit nezměrnost jeho Agonie, je vidět v ní úzkost,

58 Tamt., str. 39: „... devenir de marveilleux instruments d'achèvement et d'union spirituels".

59 P. Teilhard, Chut'žit, str. 47.

60 Tamt., str. 55. 
která odráží všechnu úzkost, která byla kdykoli prožita, celé utrpeni vesmíru. Během svého Umučení Kristus pocit'oval, že nese na své duši, sám a zbitý, váhu veškeré lidské bolesti - ve fantastické syntéze, kterou žádná slova nemohou vyjádřit. To všechno vzal na sebe a to všechno vytrpěl. Když tuto naši bolest vpustíme do oblasti jeho vědomí, promění ji.“61

Právě proto, že se Bůh osobně ponořil do všech druhů utrpení i smrti, kterou nakonec přemohl, a lidské utrpení je utrpením jeho vlastního vyvíjejícího se těla, dokáže způsobit, že ,život povstane z nejtemnějších hlubin svých stínư“. ${ }^{62}$ To znamená, že dokáže najít v každé izolaci a rozpojení nový vztah k celku, novou syntézu, vytvořit nové spojení, a tím i růst tam, kde to již není v lidských silách. Právě to je v citátu pojmenováno slovem syntéza, které Teilhard používá pro sjednocující činnost ducha, tzn. vytváření vazeb. Tato syntéza ale „nerozbíjí škodlivé vazby, které byly nenapravitelně uzavřeny v minulosti. Pouze je integruje do vyššího řádu. Nutí je pracovat pro dobro“. ${ }^{3}$

Zde tkví evoluční význam zdánlivě nenapravitelných disharmonií v noosféře. Takto získaný „vyšší řád“ může mít různé podoby. Díky nemožnosti jednat se člověk může nakonec dostat k činnostem, k nimž by se jinak nikdy nedostal a u nichž se ukáže, že otevírají mnohem širší možnosti než ty předchozí: „Vidíme člověka vycházet zušlechtěného, přetaveného a obnoveného ze zkoušky nebo i pádu, který ho musel zdálo by se - navždy oslabit nebo srazit k zemi."“64 Růst duše může spočívat také v nové kvalitě duševní energie: v získání nové síly po překonání strachu, zášti nebo ponížení.

61 P. Teilhard, Écrits, str. 77: „Nous avons bien peu de données sur la façon dont Notre-Seigneur éprouve son corps mystique, pour en jouir. Mais nous entrevoyons un peu comment Il peut en recueillir les peines; et c'est même la seule façon d'apprécier l'immensité de son Agonie que d'y reconnaître une angoisse, écho de toutes les angoisses, une souffrance, cosmique'. Au cours de sa Passion, Jésus a senti porter sur son âme, seule et broyée, le poids de toutes les douleurs humaines; en une prodigieuse et ineffable synthèse, Il les a toutes adoptées, resssenties..."

62 Tamt., str. 355: „[L'effort ... que la confiance en Jésus rend possible] ... du plus profond de ses ombres ... surgir la Vie“.

63 Tamt., str. 354: „... ne rompt pas les liens mauvais contractés irréparablement dans le passé. Elle les intègre seulement dans un ordre plus élévé. Elle les force à servir au bien".

64 P. Teilhard, Chut'žit, str. 49. 
Také války nebo revoluce mohou být př́ležitostí $\mathrm{k}$ pokroku, např̀. ve vědeckém výzkumu. Při těchto násilných transformacích dochází k rozpadu a uvolnění obrovské energie způsobem, který je destruktivní a dotýká se celých skupin, ale také může občas rychle přispět ke vzniku nových, komplexnějších forem uspořádání. Významu války, této „krizi růstu“ ", 65 věnoval Teilhard velké množství textů, ačkoli v komentáŕích a zmínkách o jeho díle zůstává tento fakt opomíjen. Jednou z mála výjimek je Jan Patočka, který v odpovědi na otázku, ,proč se energetická proměna světa musí dít válečně“, prokazuje vzácné pochopení Teilhardova stanoviska: „Protože válka, akutní opozice, je nejintenzivnější prostředek rychlého uvolnění akumulovaných sil." 66 Rozhodně z toho ale neplyne, že válka nebo utrpení jedince vždy urychlují evoluci, protože pokud se nová forma „tvoří“ za pomoci destrukce, nenávisti nebo strachu, bude s velkou pravděpodobností plodit další formy zla, které už pak nemusí být $\mathrm{v}$ lidských silách nijak napravit.

Existují také umenšení, která se nezdají být vyvážena žádným ziskem ve smyslu rozšiřrení vědomí a vztahových sítí. „Předčasná úmrtí, nesmyslná neštěstí, oslabení postihující nejvyšší oblasti našeho bytí.“67 Smysl mohou získat, pokud utrpení chápeme jako zdroj nevyužité „potenciální energie“" 68 což ale Teilhard už blíže nevysvětlil. Chápu to takto: Z každého narušení jednoty, provázeného u organismů bolestí, se uvolňuje velké množství energie. V situaci, kdy nemůže z nějakého důvodu posloužit jako zdroj nového spojení a řádu jedinci, který bolest zakouší, ji lze nabídnout jiným bytostem jako dar. To je umožněno právě tím, že každé utrpení je také utrpením Kristova těla.

Symbol kříže poukazuje na to, že z jakéhokoli místa, i ze zdánlivé prázdnoty nebo rozkladu, vede př́mé spojení k centru, ke Kristovu srdci, energetické bráně celého vesmíru. Kříž je symbolem této všudypřítomné komunikační sítě, „,nervové soustavy“ Kristova těla. Po tomto spojení lze vyslat do centra cokoli, i vlastní bolest. Kristus pak může užít vyslanou „energii bolesti“ jako zdroj pro nový růst, ale na jiném místě celku světa, kde je to zrovna nejvíce žádoucí. Pokud člověk dokáže tuto

65 P. Teilhard, Écrits, str. 421: „La Guerre était une crise de croissance.“

66 J. Patočka, Kacírské eseje o filosofii dějin, Praha 2007, str. 109.

67 P. Teilhard, Chut'žit, str. 49.

68 Viz např. P. Teilhard, L'Activation, str. 65. Smysl zdánlivě nesmyslného utrpení řešil v rozmluvách se sestrou upoutanou na invalidní vozík. K tomu srv. P. Teilhard, Duchovni energie utrpení, in: P. Chauchard (vyd.), Pierre Teilhard de Chardin: Svatá hmota, Olomouc 2005, str. 21-23. 
nabídku učinit, proměňuje se také jeho bolest, kterou svojí vlastní mocí nebyl schopen změnit ve tvůrčí aktivitu. Známkou toho je, že odcházejí pocity ponížení, sebelítosti, nenávisti a dostavuje se pocit síly, ačkoli bolest nemizí. Předpokladem proměny utrpení v růst je podle Teilharda ctnost víry, tzn. osobní důvěry v Boha, která je podle Teilharda „nejvyšší organizující síla vesmíru“. ${ }^{9}$ Jejím prostředkem je modlitba, osobní rozhovor s Bohem. Díky modlitbě může mít i duše podle lidského měřítka bezmocná značný vliv na události ve světě - když se Bohu nabídne jako zdroj energie pro jeho úmysly.

\section{Závěr}

Cílem evoluce je podle Teilharda dosažení maximální možné komplexity - jednoty v různosti. Komplexní systém existuje jako mnohost sjednocená na základě formy, pravidel uspořádání. Přitom každý komplexní celek prochází při svém růstu fází transformace spojené s chaosem, ve které se mění uspořádání a vztahy mezi jeho částmi. Při transformacích dochází nutně, tj. na základě evolučního zákona, ke vzniku různých disharmonií, nepořádků - nedokonalých realizací obecných forem. Právě disharmonie jsou ale $v$ Teilhardově teorii nezbytným předpokladem evoluce a růstu vědomí. Bez nich by se vývoj jen cyklicky, věčně opakoval a žádný nový tvar by nemohl vzniknout.

Bolest, a dokonce ani smrt nejsou proto v Teilhardově teorii primárně chápány ,jako trest, který odčiňuje hřích, ani výlučně jako faktor nebo symptom roztržky se zemí, ale spíše jako podmínka vývoje a cena, kterou je za něj nutné zaplatit““. ${ }^{70}$ Bolest je nutná pro udržení jednoty komplexního systému, patrně není jiný způsob, jak by se dala v organismu přenášet zpráva o narušení jednoty celku než pomocí bolesti, a mírná bolest je také spolehlivým ukazatelem všech typů růstu. Smrt je v Teilhardově teorii podmínkou přechodu do nového řádu bytí. Každá bytost, a tím spíše bytost lidská obdařená sebevědomím, má jedinečnou hodnotu. Osobní nesmrtelnost v prrípadě lidské duše znamená, že nese vědomý, nezastupitelný obraz světa, ovlivněný historií vývoje všech bytostí, které patří do její vztahové sítě, včetně buněk a atomů vlastního těla. Tento „obraz“ uchovává něco jedinečného z historie vesmíru a po

69 P. Teilhard, Écrits, str. 358: ,... la force organisatrice suprême de l'Universe“.

70 Tamt., str. 103: „... la souffrance n'apparaît pas immédiatement comme une peine expiatrice, ni uniquement comme un facteur ou un signe de rupture avec la Terre, mais bien plûtot comme la condition et la rançon de Progrès...“. 
smrti, závěrečné transformaci duše, se zachová díky Forma mundi, Kristu, pro konečnou fázi vývoje - pléróma.

Důvodem „drsného nastavení evolučního řádu je absolutní hodnota svobody, a to nejen lidské. Cílem stvoření je umožnit tvořit všem bytostem v universu, tedy dovolit jim, aby do plnosti bytí přinesly svůj vlastní autentický prŕspěvek vytvořený z materiálu daného vesmíru Bohem počáteční energie stvoření a jednoduchých evolučních pravidel -, ale ve svém obsahu jedinečný, podobně jako je jedinečné umělecké literární dílo napsané na základě společných pravidel gramatických. Teilhardovými slovy: „Bůh tvoří věci tak, že se samy tvoří."71 Počet evolučních „výtvorư“ je v možnosti nekonečný, a čím více se jich podaří realizovat, tím lépe bude božská energie využita.

Bolest a utrpení vyjadřují fakt, že každá bytost lpí na již vytvořeném stupni komplexity a změně se poddá jen tehdy, když má záruku, že povede $\mathrm{k}$ dalšímu růstu. Bytí je tak žárlivě střeženo, že většina bytostí by spíše setrvala na jeho získaném stupni a předání potomkům, než aby riskovala další vývoj s nejistou budoucností. Proto evoluce na všech sférách postupuje spíše proti ,vưli“ zúčastněných bytostí, tedy díky nutně vznikajícím transformacím a disharmoniím, které z nich pocházejí. Kombinace disharmonií a lpění na bytí ale zaručuje, že nové tvary vznikají samouspořádáním.

Zlo může z disharmonií vzejít až na úrovni noosféry, kde díky schopnosti lidského sebevědomí zacházet s abstrakty nemohou vznikat komplexní systémy jinak než záměrnou činností tvorby pravidel a ideálů. Jejich zkusmá aplikace nutně vytváŕí různé typy nejednoty a chaosu, ale zároveň je koexistence rozporných hodnot a ideálů hlavní silou evoluce (rozvoje kultury a šíře lidského vědomí) lidstva jako druhu. Strach z nejistého výsledku transformací, silná touha držet jednou získaný stupeň bytí nebo ztížená možnost realizovat se jako osobnost v prostředí s omezenými zdroji, mohou vést k pocitu umenšení a ponížení a $\mathrm{k}$ hledání viníka za tento stav, a tím ke vzniku specifického naladění duše, ze kterého se rodí zlo - záměrné vytváření „,nejednoty“.

Zlo navrhuji vymezit jako jednání (včetně změn způsobených nekonáním z lhostejnosti), které má uskutečnit cíl motivovaný „zlým naladěním “ duše. Tímto naladěním je pocit ponížení spojený s označením nějaké bytosti (včetně sebe sama) za špatnou samu o sobě, který vzniká ze strachu z umenšení komplexity. Cílem stanoveným na základě takového motivu je záměrné narušení vztahových sítí. Aby mohl člověk

71 P. Teilhard, Journal, str. 313: „Dieu fait se faire les choses.“ 
tvořit správné formy uspořádání, musí je být schopen rozlišovat na škále lepší a horší a také kritizovat vztahy na jejich základě vzniklé, což jsou schopnosti, které zvíře nepotřebuje. Možnost označit nějakou bytost za špatnou samu o sobě a nepatř́ící do sítě sdíleného bytí je ale zneužitím této schopnosti.

Navrhuji tedy chápat zlé jednání jako zneužití specificky lidské schopnosti souzení. Jednání, které je vedeno kritikou nějakého chování (vztahů) člověka, má jinou kvalitu než jednání založené na označení sama tohoto člověka za špatného a hodného vyloučení nebo ponižujícího zacházení. První z nich respektuje důstojnost lidské osoby a možnost najít (byt's vynaložením velkého úsilí) pro každého místo ve „vztahové síti“, druhé tuto možnost popírá nebo na ni z lhostejnosti nedbá, a tím rozšiřuje pocit ponížení a umenšení a př́ležitost $\mathrm{k}$ dalšímu zlému jednání. ${ }^{72}$

Pokud jsou ale disharmonie nutné a pokud jsou nutná i morální selhání, jak Teilhard opravdu tvrdí, klade se z hlediska etiky zásadní otázka: Jak poznat zlo, proti kterému je třeba bojovat? Rozhodně neplatí, že by se lidstvo mělo vzdát své schopnosti vymýšlet pravidla organizace, protože právě v tom spočívá jeho evoluční úkol. Také strach a obranná agrese jsou občas nezbytné, už jen proto, že př́liš ukvapená změna může komplexitu umenšit ještě víc než zdravý konzervatismus, a násilí je za mnoha okolností oprávněné, pokud je jeho účelem chránit nebo umožnit růst. Problém noosféry tkví v tom, že umenšení způsobené zlým jednáním není automaticky, tzn. čistě na základě zákona diferencující jednoty, nahrazeno nějakým typem růstu na jiném místě celku, jako je tomu v ostatních sférách evoluce, kde pravidla nevznikají záměrnou činností. Obrácení zla v dobro je tedy na rovině noosféry zcela závislé na aktivitě člověka. Zlo je odsouzeníhodné především proto, že chaos nejednoty ještě zhoršuje a vytvář́ bludný kruh: Nenávist plodí nenávist a ponížení další ponížení.

Každé zlo může být potenciálně obráceno v dobro, ale člověk se o to musí aktivně zasadit a není čistě v jeho moci to dokončit: Musí přitom nutně spolupracovat s tvořivou silou Boží. Ctnost víry takovou spolupráci umožňuje (a v Teilhardově teorii není tato ctnost dána pouze křest’anům). Poškozený vztah způsobený zlým úmyslem se stává dobrým tehdy, když

72 Teilhard toto rozlišení výslovně nečiní, lze ho najít např. u G. K. Chestertona: „Křestanství rozdělilo zločin od zločince. Zločinci povinni jsme odpustiti až do sedmdesáti sedmikrát. Zločinu nesmíme odpustiti nikdy. ... Nechává to místa čiré ošklivosti k nespravedlnosti, která jest spravedlivému velikou okrasou. A nechává místa čisté citlivosti k lidem jakožto k lidem, kteráž jest vším kouzlem milosrdného.“Viz Orthodoxie, přel. A. L. Stř́iž, Stará Říše 1918, str. 153. 
se podaří najít možnost jeho využití k nějakému růstu. Nalezení takové možnosti může pocházet jak od toho, kdo byl původcem zlého úmyslu, tak od toho, kdo zlým vztahem trpí, ale také od nezúčastněné třetí osoby.

Transformace ale nemusejí být nutně provázeny zlem (nutný je pouze vznik disharmonií), $v$ dokonale sladěném celku by mohly připomínat např. radost $\mathrm{z}$ tvoření nějakého náročného díla vyžadujícího značné úsilí a každá disharmonie by byla využita pro větší komplexitu celku. Úkolem lidstva je podle Teilharda sjednotit se do jednoho celku, který by zvýraznil jedinečnost každého člověka. Díky dokonalé formě (dokonalým pravidlům organizace) by bylo každé bytosti umožněno vyjádřit svůj jedinečný pohled na svět činností, která zároveň podporuje sebevyjádření dalších bytostí. K tomu lze postupně směřovat staráním se o kvalitu vztahové sítě, kterou každý jedinec kolem sebe vytváríi, a o její rozšiřrování, což znamená také vyvarovat se jednáni motivovaného ohodnocením nějaké duše nebo skupiny jako špatné. Cestou k tomu je učit se zvládat strach a pocity vlastního umenšení bez zášti a nenávisti k ostatním duším i své vlastní.

Co se týká křest’anské nauky o dědičném hříchu, Teilhard tvrdí, že v evolučním vesmíru se theologům ,nabízí lidská solidarita ještě mnohem těsnější než ta, kterou hledali v lůně pramatky Evy, totiž solidarita plynoucí z neobyčejného vnitřního propojení světa kolem nás “، ${ }^{73}$ Jelikož disharmonie vznikají nutně, přenášejí se do dalších generací také jejich následky, kterými jsou obecně různé formy nedostatku zdrojů. Kromě toho nikdy není dopředu zřejmé, jak se která forma organizace v praxi osvědčí, takže k mnoha příležitostem ke zlu dochází jen kvưli této nutné metodě pokus - omyl. Dědí se tedy nejen chaos jako následek špatných forem, ale také nutnost pokračovat $\mathrm{v}$ organizaci formou pokusů. Takto pochopený dědičný hřích však Teilhard neoznačuje jako zasloužený trest, ale jako vzájemné předávání díla bytí, které má člověka nutit ke spolupráci s Bohem a poznávání zákonů evoluce.

Nicméně do Teilhardova díla je možné vřadit také myšlenku utrpení jako trestu. Boží vůle je vyjádřena hlavním evolučním zákonem diferencující jednoty. Správná forma sjednocení je taková, která umožňuje sebeurčení a vzájemně se doplňující různorodost. V noosféře se za novou formu musí vždy zaručit jednotlivec nebo skupina. Lidé, jejichž úkolem je starost o pravidla a ideály společenského uspořádání (např. státníci, kněží, vědci, kulturní činitelé, umělci a filosofové), mají proto největší odpovědnost za podobu světa. Nejvýraznějším zdrojem zla je nenávist

73 P. Teilhard, Jak věrim, str. 128. 
$\mathrm{k}$ jinakosti (včetně nelásky $\mathrm{k}$ sobě jako odlišné bytosti), která jde př́ímo proti Božímu zákonu diferencující jednoty. Pokud lidé vytvářejí formy založené např. na obvinění určitých lidských skupin, ras, národů nebo vyznání z př́íciny zla, budou se celky vytvořené na jejich základě měnit velmi dramatickým a násilným způsobem. To lze chápat jako přirozený, „automatický“ trest za špatné formy sjednocení, tedy za neuposlechnutí Božího zákona, který ale zasahuje také bytosti, jež nejsou viníky těchto forem, což je jeden $\mathrm{z}$ aspekti̊ dědičného hříchu (o nápravu jsou často nuceny se postarat právě nevinné oběti).

Člověku byla dána moc tvořit pravidla kvůli tomu, aby se mohl stát skutečným spolutvưrcem, spolupracovníkem Božím. Projevy zla a selhání lidských organizací by neměly vést $\mathrm{k}$ rezignaci, ale $\mathrm{k}$ touze po spolupráci na tvoření Těla Kristova s Kristem samým, Centrem světa, a to jak na osobní, tak kolektivní rovině. Odpor k bytí samému je problémem výhradně lidským, a proto výhradně člověku nabízí Bůh osobní pomoc. Díky Kristově činu je každé zlo a utrpení v možnosti proměnitelné v novou cestu, spojení a sdílení. Tato možnost je symbolizována křížem, znamením evoluce. Víra, která je ve své nejvyšší podobě důvěrou v Kristovu moc, umožňuje úsilím a spoluprací se stvořitelem překonat každé utrpení a říci: „Vše co přichází, je hodno lásky.“74 To bylo také heslo Teilhardova života. ${ }^{75}$

\section{ZUSAMMENFASSUNG}

Der Artikel setzt sich mit dem Thema des Leids und des Bösen in Teilhard de Chardins christlicher Evolutionstheorie auseinander. Der Ursprung des Schmerzes und des Bösen wird auf die Evolutionsphase der Transformation und des Chaos bezogen. Im Beitrag wird Teilhards Auffassung, laut der der Tod und die Disharmonie im All natürlich sind, sogar einen positiven evolutionären Beitrag leisten, dargelegt. Demgegenüber ist das Böse nicht natürlich: Es geht aus einer unbewältigten Transformationsphase hervor; sein Hauptmotiv ist Angst und ein Gefühl

74 „Tout ce qui arrive est adorable.“ Citát z díla Leona Bloye uvádí Teilhard v několika nepublikovaných dopisech. Např. dopis pro Beaulieu z 20. 9. 1947; pro Th. Monoda z 25. 8. 1947. (Sbírka dopisů ve Woodstock Theological Library, Georgetown University, Washington, D. C.)

75 Článek vznikl v rámci projektu „Opomíjené stránky v díle Teilharda de Chardin“ (č. 165515) realizovaného na Filozofické fakultě Univerzity Karlovy $\mathrm{v}$ roce 2015 a podpořeného Grantovou agenturou UK. 
der Erniedrigung und es hat gestörte Verhältnisse zur Folge. Schließlich wird Teilhards Auffassung des Kreuzes als Symbol der Evolution untersucht.

SUMMARY

The topic of the paper is the concept of suffering and evil in the Christian theory of evolution of Teilhard de Chardin. The origin of suffering and evil is connected with the evolutionary phase of transformation and chaos. The paper explains Teilhard's opinion that, whereas death and disharmony are natural in the universe and they can even have a positive significance in evolution, evil, on the contrary, is unnatural, arises from an unmanaged stage of transformation, its main motivation is fear and feeling of humiliation, and its consequence is a breakdown of relationships. In conclusion, Teilhard's understanding of the cross as a symbol of evolution is explained. 